\title{
18 Energy transition
}

\author{
A challenge for the management of the cultural landscape \\ UlfIckerodt and Matthias Maluck
}

\begin{abstract}
Landscape redevelopment in the wake of the Energiewende (energy transition) poses a hitherto unparalleled challenge for heritage management, as is the case in the federal state of Schleswig-Holstein. In contrast to localised mining of raw materials, for example, the energy transition affects the entire German planning area, including its Exclusive Economic Zone in the North and Baltic Seas. New spatial demands emerge in addition to known stakeholder interests. Within the framework of this contribution, strategies for how heritage management can deal with the consequences of developments in the renewable energy sector will be explained using the Schleswig-Holstein case. Several of the ideas presented here are exemplary and can be transferred to other areas of work. For this purpose, the statutory basis and preconditions for - as well as goals of - a sustainable management of archaeological monuments and cultural landscapes shall be illuminated. The tools presented here cover the spectrum from 'interest areas' to the concept of 'heritage value', which guides decision-making processes. Two projects - the $380 \mathrm{KV}$ high-voltage power line Heide-Niebüll and 'Regiobranding' — are used as showcase examples.
\end{abstract}

Keywords: heritage management, spatial planning, interest areas, heritage value, regiobranding

The expansion of the renewable energy sector poses new challenges (Reinke 2016) to which the State Archaeological Department of the northernmost German state of Schleswig-Holstein (Archäologischen Landesamtes Schleswig-Holstein 2015) must respond, as it is affected in many different

Egberts, Linde \& Schroor, Meindert (eds.), Waddenland Outstanding: The History, Landscape and Cultural Heritage of the Wadden Sea Region. Amsterdam: Amsterdam University Press, 2018 DOI: 10.5117/9789462986602/CH18 
ways. Aside from the repercussions of 'energy crops' or solar parks on agricultural land use (Reinke 2016: 469; Ickerodt et al. 2013), which will not be discussed here, it is first and foremost the construction of an energy infrastructure that will have a great impact in terms of wind power plants, high-voltage power lines, electric power transformation stations and the like. Its development occurs in the North Sea's exclusive economic zone of Germany and on firm land and passes through Schleswig-Holstein's territorial waters and its maritime and submarine cultural landscapes (Ickerodt \& Warnke 2017 and others). Given Jochen Bölsche's critical outcry that the German landscape was suffering a slow death as it was increasingly being intersected, overgrown by housing areas and destroyed (1983; Trommer 2016: 39), ${ }^{1}$ one could pose the crucial question: at what point do our historic cultural landscapes or characteristic landforms lose their historic values?

Consequently, the protection of cultural landscapes is not entirely a subject-specific issue. The discussion on negative and positive impacts is influenced by competing overriding political goals. For instance, a guideline on an integrated energy and climate concept for Schleswig-Holstein (2011) was passed with political consent. The concept is designed as spatial planning policy (Kühnau 2016: 393) and links the overriding but abstract goals of the politically motivated Energiewende ('energy transition', i.e. the transition to alternative low-carbon power production) with the legally binding obligation of monument and landscape protection. The latter are commonly within the framework of their own subject or remit, although factors concerning public services and economic development must be taken into account as well.

Against this background, authorities dedicated to the protection of cultural landscapes are obliged to deal with the growing spatial demands (Trommer 2016: 41-42) and must come to terms with all stakeholders, of which heritage management professionals are only one group among many (Woltering 2017:121). Their protected goods — in this case the archaeological heritage as an integral part of historic cultural landscapes — are situated next to wind, biogas and solar plants, transformer stations as well as subterrestrial and overhead high-voltage power lines; all manifest elements of the renewable energy sector's spatial requirements. In order to achieve the goal of a sustainable protection of the cultural landscape (Ickerodt 2016 and others), policymakers, planners, contractors, conservationists and heritage experts must actively work together in order to reconcile diverging interests.

1 Although this was within a different context, the awareness of cultural landscapes has drastically improved since it was published. 
Figure 18.1 The expansion of the renewable energy sector is causing change. As the example of Pellworm shows, traditional farming is shifting towards energy production with wind power, biogas plants and photovoltaics. Agricultural historical cultural landscapes are changing towards the production of energy, and new 'transformation' or 'energy' landscapes are evolving.

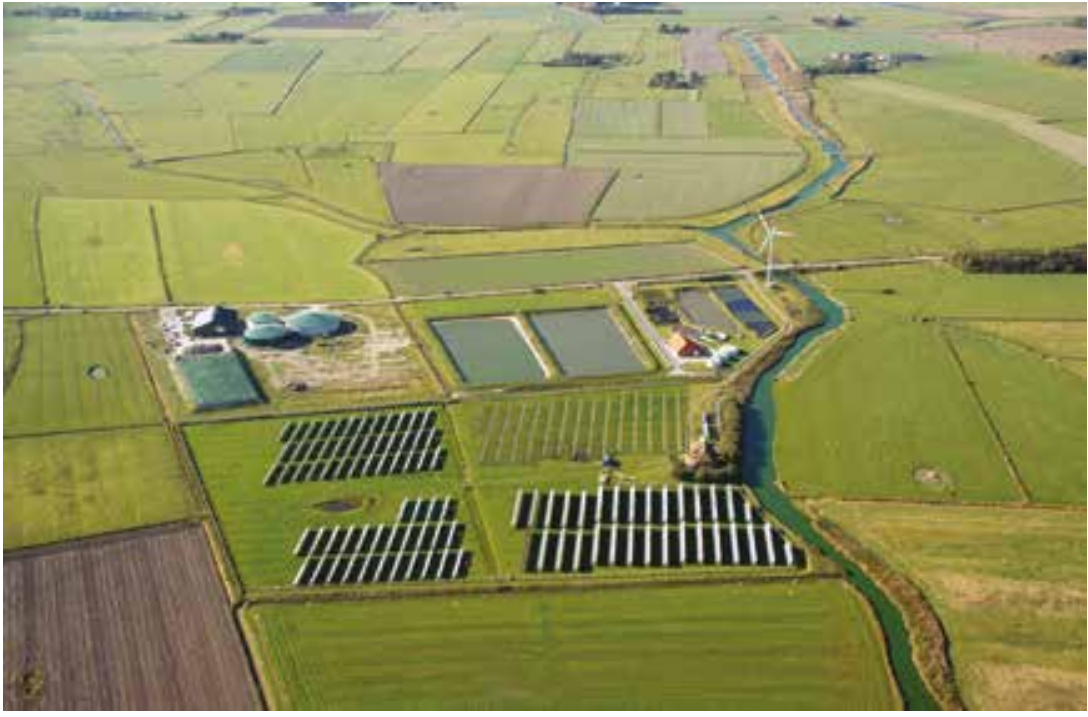

Courtesy of Archäologisches Landesamt Schleswig-Holstein, Linda Hermannsen

The action radius of cultural landscape management requires a change of perspective on the part of the state's archaeological monument protection authority, which has long taken a subject-driven approach. Stakeholders often put undue emphasis on academic and historical-cultural aspects and have pursued research questions of personal interest, while matters of administration and the law were perceived as disruptive trivialities and therefore neglected. Nonetheless, one of the crucial tasks of a state archaeological authority is to coordinate necessary research into the protection of monuments within the legal framework.

In practical terms, this means that the State Archaeological Department, or ALSH, should provide adequate data sets for planning, as does nature conservation, through which the protection of the cultural landscape can be implemented. The evaluation criteria must be based on verifiable standards (Ickerodt 2014; Zölitz 2016), whose procedure will be addressed in more detail below. The appropriate administrative tools are the active involvement on all levels of planning (Kühnau 2016; Woltering 2017) as well as the use of 
all available tools under the plan approval procedure, like environmental impact assessments (Reiter 2016). The technical content of the evaluations and decisions have to be calibrated to the legal framework according to the scale necessary for the required level of planning.

\section{Basics and preconditions for a sustainable protection of the cultural landscape}

In general terms, the protection of the cultural landscape and other aspects related to archaeological and conservational objective can be summarised by four main goals: it is all about documenting, studying, narrating, and — in order to enhance the qualitative awareness of cultural landscapes and their archaeological potential — also preserving. Meanwhile, the term 'preserving' incorporates the paradoxical notion of uniting both preservation and change as aspects of a development path. The catchphrase 'history matters' can be used as a yardstick of development path interdependencies. Therefore, the sustainable management of cultural goods and landscapes in Schleswig-Holstein not only encompasses those explicitly protected by the ipsa lege principle - i.e., listed cultural and natural monuments - but also incidental elements of the cultural landscape that are not in themselves monuments or landmarks.

Both listed monuments and unlisted elements form cultural landscapes, the unique attributes of which need to be ascertained. Their interplay expresses an intrinsic quality of spatiality. As a regional unique characteristic, this expression is closely linked to the quality of life and services for the public, playing a vital role in moulding regional identity. Thereby, a wide spectrum of civic life is affected, including the right of basic general and adult education, recreational learning, content for school curricula, as well as the encouragement of civic and honorary commitment.

On a supraregional scale, this aggregated value can be seen as an important location factor within the context of European and German regional competition. It includes services for the public, like sustainable resource management, but also issues like innovation and growth. The development of the tourism sector and the potential for local recreational activities are aspects that are just as relevant as the infrastructural development and the politically driven energy transition. Specifically, this includes all infrastructural developments: apart from road construction, the extension of broadband services, the railway, maintenance works, flood prevention and the power grid. This last is particularly strongly affected, as it is the stated political aim to implement the energy transition on a regional level 
to an acceptable degree. The state has raised awareness and acceptance of this process through numerous public relations events.

\section{Goals of heritage management in cultural landscapes}

Aside from the management of archaeological monuments, their protection is a primary goal. Within the current legal framework of Schleswig-Holstein, the protection can be object-based but it can also be expanded to encompass entire cultural landscapes (Denkmalschutzgesetz 2014). The goal is a sustainable use of all resources, which is reflected in the great emphasis on planning as part of ALSH's mission. In order to make the public responsibilities more transparent and explicable, four evaluation parameters were established for archaeological monument protection, namely historical, spatial, vertical and seasonal coherency. These are adequate benchmarks for an interdisciplinary exchange when addressing the protection of monuments, cultural landscapes and the environment (Stobbelaar \& Hendriks 2006: 6; see also Ickerodt 2016).

Historical coherency is the result of an assessment of development path dependencies or similar landscape biographic analyses. Their aim is to analyse the societal identity in the context of its historical dimension and its manifestation in the anthropogenic use of space, which in turn has to be seen in the context of the environmental preconditions. Historical coherency offers a suitable interface for achieving a balance with environmental protection goals. Several monument precincts and regional cultural landscapes can become or extend habitats for faunal and floral species. It is important to note, however, that the strategies for monument and environment protection can be different or even diametrically opposed.

Spatial coherency is synonymous with the expansion of the object-based historical coherency onto a holistic level of historical spaces. These spatial references not only render unique characteristics landforms but could — if they enhance the appreciation of monuments or groups of monuments - be an intrinsic part of the heritage value. As such, they have to be considered as intangible aspects of the cultural heritage and their essence is commonly captured by the term genius loci. Elements of the cultural landscape - monuments and their surroundings — ideally form historical reference areas. These are the results of decision-making in the past, essential features of which can be still experienced. They offer the observer an emphatic and authentic glimpse into a lived life and thus a contemplative self-awareness in a historical dimension.

Vertical and occasionally also seasonal coherency are metonymic for the retention of specific deposition conditions of the material cultural heritage 
and for the appreciation of intangible spatial relationships of inanimated and animated elements of cultural landscapes. Both aspects have a source value, for which reason an in situ preservation is desirable and occasionally offers opportunities for cooperation between the heritage and natural protection sectors.

These four categories form the basis for the procedural sustainability evaluation. These are based on the assessment of the long, medium and shortterm impact of developments and the viability of the cultural landscape and its monuments. In order to achieve this goal, Schleswig-Holstein is committed to pursuing a planning-oriented management of its archaeological heritage.

\section{Interest areas}

A well-performing cultural landscape protection requires not only the legal competence of a public authority, as in the case of the ALSH, but also good communication on new developments at an early stage. This is not always the case, as developers are not always aware of the legal and professional framework. In order to determine the intended level of protection for a site, planners as well as permit and construction supervision agencies have to be provided with elementary guidelines, which enable them to decide whether the ALSH has to be involved or not.

In order to implement this decision guidance, the ALSH has developed the concept of archaeological interest areas, which enables planners to determine - often merely through a visual check — whether an area falls into the remit of the ALSH's responsibilities (Archäologisches Landesamt Schleswig-Holstein 2015). As the culture sector is not within the jurisdiction of the German federal government but rather its federal states (Bundesländer), there are a number of differences in archaeological management practices, which incooperate different legal, managerial and scientific notions. A harmonisation of these various notions is negotiated on the federal level at the Kultusministerkonferenz conference of ministers of culture.

Interest areas and their associated archaeological potential are mapped and edited for all planning levels, i.e. for the regional land use plan and above. On this basis, the significance of the archaeological heritage can be verified at an early stage in areas where, for instance, extensive development is scheduled. This enables planners to factor in the time required for archaeological investigations and adds to the overall planning security. The interest may concern perimeter protection or developer-funded excavations in accordance with the Valetta Treaty. 


\section{Heritage value as a basis for decision-making in planning processes}

The Denkmalwert (heritage value) has proven to be a suitable concept for academically justifiable, legally valid, conservational decision-making (Kallweit 2013: 28-31). From the archaeological and heritage management perspective, the heritage value consists of several components (Ickerodt 2014). These are nominally the archive value, the source value, the state of preservation and the uniqueness, and includes aspects of authenticity, historical integrity and experienceability. These have to be ascertained in the course of the planning procedure and form the basis of the management goals. Aside from the physical preservation and the storage conditions, another responsibility may arise from the need for perimeter protection around the archaeological site, and the preservation of the essence of the cultural landscape. Moreover, the heritage value encompasses academic, legal and practical administrative aspects, which genuinely and credibly substantiate the historical importance of the site in relation to its spatial context. Ideally, the goal would be a holistic and complete transmission for preserving for future generations the essence of the site as well as the cultural landscape in which it is embedded.

The archaeological-conservational-professional interest is correlated with the respective administrative framework. The basic goal of substance preservation and/or perimeter protection can only be relativised in exceptional cases. This can occur in marginal areas when, for instance, other planning goals are prioritised. In other cases such as emmissions control, a weighing of interests can take place beforehand. This raises the question, however, of what stage of the planning process the archaeological interest should be taken into account in order to prevent being overrided on a regional planning level.

The benchmark for the assessment of whether an archaeological heritage site is under threat is set by an observer receptive to the goals of monument protection, who must be able to reproduce the technical evaluation of the archaeological authority. A prevention or mitigation of the impact can be best achieved by early and calibrated planning. With respect to the designation of wind energy priority areas, in which the interests of the archaeological cultural landscape were not yet considered, the Umgebungsschutz (protection of archaeological perimeters) still applies for the later authorisation process and does not result from early priority zoning.

In view of potential projects, it needs to be noted that substantial consequences may arise from mitigation measures for protected sites 
Figure 18.2 The erection of wind power plantshas repurcussions for the landscape that go far beyond thethe actual location of the plants, as demonstrated by the example in the northern part of the district of Nordfriesland: it is accompanied by the construction of infrastructure, trenches for cables, electric power transformation stations and highvoltage power lines.

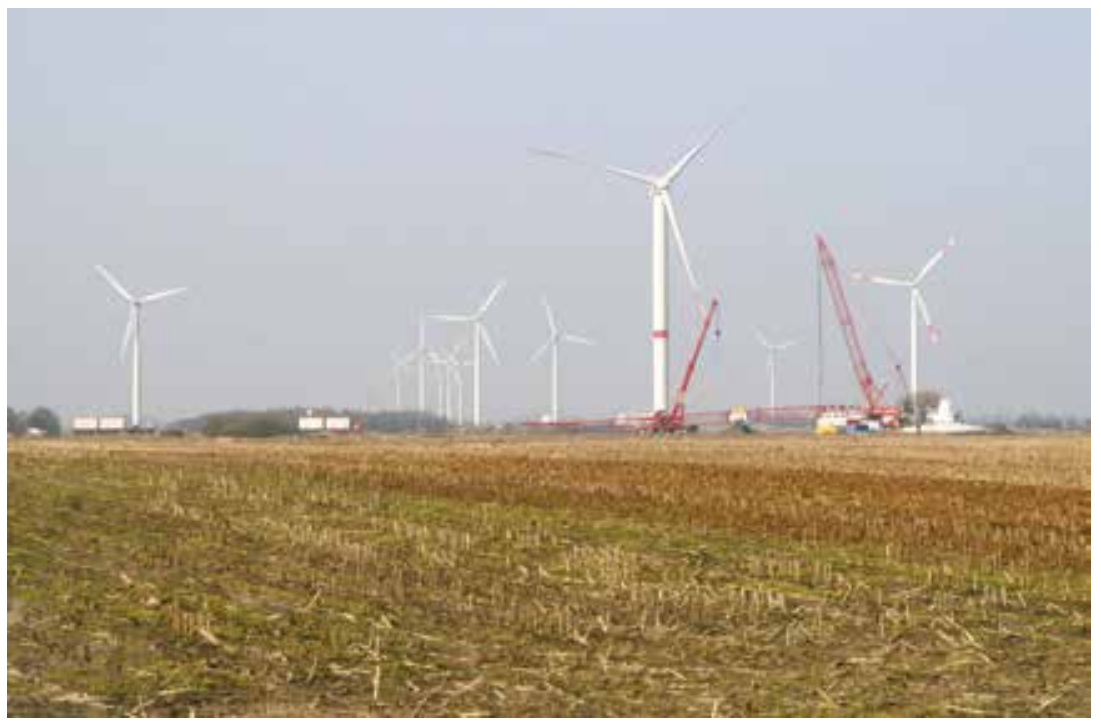

Courtesy of Archäologisches Landesamt Schleswig-Holstein, Linda Hermannsen

(emmissions, landscape preservation plans, etc.). In order to prevent or reduce such consequences, it becomes necessary to examine concrete measures to mitigate the project's impact, particularly through project alternatives or even the Nullvariante (abortion of the project) (subject to Gesetz über die Umweltverträglichkeitsprüfung). Possibilities for compensatory measures in the course of the implementation process (as common in environmental protection) are only very limited due to the fixed location and the unique nature of archaeological sites as well as the peril of political instrumentalisation (e.g. indulgence or ransom payments).

\section{Example: The 38oKV high-voltage power line Heide-Niebüll}

For the construction of the $38 \mathrm{okV}$ high-voltage power line in the summer of 2013, the ALSH contributed two reports to an environmental impact assessment (Kühlborn 2014) in which route corridors through areas with 
the lowest archaeological potential were identified. In accordance with the legislative framework of the time, the outstanding and common archaeological monuments and their relationship to the historical cultural landscape were examined. The starting point of the assessment was the 6oo-metre-wide corridors that had been designated for the later power line. In view of the great importance of the archaeological monuments - now protected sites under the ipsa lege principle - the corridors were extended at the ALSH's discretion by a buffer zone of 1,00o metres on each side, which became subject to a detailed re-evaluation of archaeological sites. The heritage value of the monuments within this zone was evaluated. The basis of this evaluation was the assessment of the source value, the state of preservation, pre-existing spatial impairments, the experienceability of the landscape and the monument's historic context within it, uniqueness, as well as preservation and sustainability issues. In this example, 72 archaeological sites were affected. A five-tier scale was used for their evaluation, with ratings ranging from außerordentlich hoch (outstanding) to sehr hoch (very high), hoch (high), bedeutend (significant) and unbedeutend (insignificant).

In the ensuing impact prognosis, the exact nature of the impact in terms of its construction, installation and operation was determined and how it would affect the substance, function and sensory integrity of the archaeological monument. A general impact was deduced from specific case-by-case impacts and likewise evaluated with the five-tier scale.

In the second phase, common archaeological sites were evaluated in a more simplified procedure. One criterion was their visibility. In the third phase, historical landscapes were evaluated.

For the quantification of 'archaeological spatial resistance', these three evaluation phases were summarised and a recommendation was issued that presented a solution in which the archaeological heritage and the cultural landscape would be minimally affected. In general, this evaluation represents a transparent and replicable procedure, which meets the requirements of the evaluation on a case-by-case basis (Kühlborn 2014).

\section{Regiobranding}

An important goal for enhancing the protection of archaeological cultural landscapes - beyond the level of current involvement as determined in the existing legislative framework - is to be actively involved in the planning processes. By the early involvement of the affected portion of the public — represented 
by interest groups or individuals - conflicting goals can be identified at an early stage while longterm goals for the enhancement of the archaeological heritage and cultural landscapes can be worked out by consensus.

On this level, other interests such as social services and business development become important. They occur together with branding processes. A concrete goal is to prevent a lopsided regional centralisation and the fragmentation of interests. Other aspects concern the improvement of the regional net product as through a better visitor flow management, for instance, or greater sustainability via civic involvement. Good knowledge of the homeland is an important factor for tourism and the commitment of the local population. Incidentally, it should be noted that goals calibrated well in advance tend to accelerate planning processes.

This interplay is currently being examined by the Federal Ministry of Education and Research (Bundesministerium für Bildung und Forschung, BMBF) within the framework of the REGIOBRANDING project as part of the FONA-initiative ${ }^{2}$ (Kempa \& Herrmann 2014; see also Ickerodt 2016: 268). The test area is the Elbe marshland of the district of Steinburg, which is a metropolitan region of Hamburg. This is a pilot sub-project in partnership between the ALSH and the district of Steinburg.

On the basis of a historical-geographical evaluation of the historical cultural landscape, and with active citizen involvement, an attempt is made to raise public awareness for historical landscapes and the archaeological heritage beyond the ordinary public participation procedures. In an externally moderated meeting, development goals are worked out and verified by the legislative framework of urban land use planning and spatial planning. The goal of this exercise is not only to garner greater public acceptance for archaeological protection issues but also to establish a more sustainable and economically prospective attitude towards local heritage (Ickerodt et al. 2015 and others).

\section{Latent images: A synoptic outlook}

The development of renewable energies and the expansion of the power supply infrastructure, which is the focus of this paper, can be currently regarded as key challenges. These are new factors and are as significant as other political goals regarding social services and business development.

2 Innovationsgruppen für ein Nachhaltiges Landmanagement (Innovation Group for Sustainable Land Management) and Innovationsgruppen Landmanagement (Innovation Groups Land Management), 2015 . 
These interests must be offset against the objective of protecting and managing the archaeological heritage with a special emphasis on preserving the nativeness of the cultural landscape.

Against this background, historical cultural landscapes represent a regional asset, which is closely connected with the quality of life and which plays a role in moulding regional identities. It is also a location factor, which becomes increasingly important within the context of European regional competition. In this area, heritage management and the protection of cultural landscapes could contribute to regional branding, preventing a lopsided centralisation and fragmentation of interests, while indirectly enhancing the regional net product. The cultural historical and environmental connection not only strengthens the local identity and ties in with the concept of a homeland; a knowledge of the past and the clandestine interplay of historical factors that shaped the land also constitutes a locational advantage, a potential that is very rarely tapped. As a 'regenerative resource', this knowledge base requires special care and appreciation. The scale in itself of the development of renewable energy infrastructure poses a special challenge, which the archaeological monument protection of the state of Schleswig-Holstein must respond to increasingly with the solutions presented here.

\section{References}

Archäologisches Landesamt Schleswig-Holstein (2015). Merkblatt Archäologische Interessensgebiete. Schleswig: Archäologisches Landesamt Schleswig-Holstein.

Bölsche, J. (1983). Die deutsche Landschaft stirbt. Zerschnitten, zersiedelt, zerstört. Reinbek: Rowohlt Verlag.

Denkmalschutzgesetz (2014). Ratified on 30.12.2014 (Gesetz- und Verordnungsblatt 2015 No. 1 p. 1-42). Retrieved from https://www.schleswigholstein.de/ DE/Fachinhalte/D/denkmalschutz/downloads/Denkmalschutzgesetz. pdf?blob=publicationFile $\& v=5$

Gesetz über die Umweltverträglichkeitsprüfung, UVPG 1990, §6: Unterlagen des Trägers des Vorhabens, section 3.

Ickerodt, U., Kempa, D., Von Malottky, B. and Huusmann, P. (2015). Regiobranding. Nachhaltiges Management historischer Kulturlandschaften in der Region Steinburger Elbmarschen. Archäologische Nachrichten aus Schleswig-Holstein, 21, 100-103.

Ickerodt, U., Schiller, G. and Roos, T. (2013). Alternative Energien und nachwachsende Rohstoffe. Umweltschutz auf Kosten historischer Kulturlandschaften - Eine schleswig-holsteinische Perspektive. Archäologisches Nachrichtenblatt, 17 (4), 311-315. 
Ickerodt, U. (2014). Was ist ein Denkmalwert? Archäologische Denkmalpflege zwischen denkmalrechtlichen Anforderungen und wissenschaftlichem Selbstanspruch. Österreichische Zeitschrift für Kunst und Denkmalpflege (ÖZKD), 68 (3/4), 294-309.

Ickerodt, U. (2016). Der Nachhaltigkeitsbegriff in der archäologischen Denkmalpflege. Versuch einer Standortbestimmung am Beispiel der denkmalpflegerischen Praxis in Schleswig-Holstein. Archäologische Informationen, 39, 265-28o. Ickerodt, U. and Warnke, U. (2017). Schutzgut submarine und marine Kulturlandschaft Nordsee - eine wissenschaftsgeschichtliche und denkmalpflegerische Betrachtung zum Kulturgutmanagement. In Recker, U., Kleefeld, K.D., and Burggraaff, P. (eds.), Kulturlandschaftsmanagement. Planung-Perspektive Vermittlung, 181-201. Wiesbaden: R. Habelt Verlag.

Kallweit, N.C. (2013). Drittschutz aus dem Denkmalschutz. Berlin: Duncker \& Humblot.

Kempa, D. and Herrmann, S. (2014). Regiobranding - Kulturlandschaft als Identitätsträger und Marke einer Region. Transformationen im ländlichen Raum durch erneuerbare Energien. Unimagazin. Forschungsmagazin der Leibniz Universität Hannover, 3/4, 64-67.

Kühlborn, M. Der Denkmalwert in der Umweltverträglichkeitsprüfung (2014). Das Fallbeispiel „380KV Höchstspannungsleitung Heide-Niebüll“ in SchleswigHolstein. Österreichische Zeitschrift für Kunst und Denkmalpflege (ÖZKD), 68, 3/4, 303-304.

Kühnau, C. (2016). Integration in die räumliche Gesamtplanung. In: Riedel, W., Lange, H., Jedicke, E. and Reinke, M. (eds.), Landschaftsplanung, 393-407. Berlin: Springer.

Reinke, M. (2016). Energiewende unter dem Aspekt der Landschaftsplanung. In: Riedel, W., Lange, H., Jedicke, E. andReinke, M. (eds.), Landschaftsplanung, 467-48o. Berlin: Springer.

Reiter, S. (2016). Umweltverträglichkeitsprüfung. In Riedel, W., Lange, H., Jedicke, E. and Reinke, M. (eds.), Landschaftsplanung, 127-141. Berlin: Springer.

Schleswig-Holstein (2011). Integrierte Energie- und Klimakonzept für SchleswigHolstein. Schleswig: Landesregierung Schleswig-Holstein. Retrieved from https:// www.schleswig-holstein.de/DE/Fachinhalte/K/klimaschutz/Downloads/IEKK. pdf?_blob=publicationFile\&v=1

Stobbelaar, D. J. and Hendriks, K. (2006). Reading the identity of place. In Van der Knaap, W. and Van der Valk, A. (eds.), Multiple landscapes. Merging past and present, 1-12. Wageningen: NWO/WUR-Land Use Planning Group.

Trommer, G. 2016. Energiewende unter dem Aspekt der Landschaftsplanung. In: Riedel, W., Lange, H., Jedicke andE., Reinke, M. (eds.), Landschaftsplanung, 39-45. Berlin: Springer. 
Woltering, U. (2017). Kulturlandschaftsgutachten auf unterschiedlichen Planungsebenen in Westfalen-Lippe. In Recker, U., Kleefeld, K.D. and Burggraaff, P. (eds.), Kulturlandschaftsmanagement. Planung - Perspektive - Vermittlung, 121-132. Wiesbaden: R. Habelt Verlag.

Zölitz, R. (2016). Landschaftsbewertung. In: Riedel, W., Lange, H., Jedicke, E. and Reinke, M. (eds.), Landschaftsplanung, 127-141. Berlin: Springer.

\section{Acknowledgements}

We would like to extend our gratitude to Christian Weltecke and Daniel Zwick (ALSH) for their support, with special thanks to Daniel for his translation of this manuscript.

\section{About the authors}

Dr. Ulf Ickerodt is deputy director at the State Archaeology Department of Schleswig-Holstein in Schleswig and head of its fieldwork archaeology unit. His research fields include archaeological heritage management and public participation. He has been involved in the Trilateral Wadden Sea Cooperation since the inception of the INTERREG-funded LANCEWADPLAN. Currently, he is involved as researcher in the REGIOBRANDING Project (among other projects).

Matthias Maluck is head of the spatial planning and international projects unit at the State Archaeology Department of Schleswig-Holstein. He has been involved in the Trilateral Wadden Sea Cooperation since the INTERREGfunded LANCEWAdPLAN. Currently, he is working on the UNESCo World Heritage Site application for the archaeological monuments of Dannewerk ('Danevirke') and Haithabu ('Hedeby') and the INTERREG-project BalticRim, which deals with archaeological heritage management and maritime spatial planning in the Baltic Sea region. 
